\title{
Ontogenetic niche shifts and resource partitioning of lake trout morphotypes
}

\author{
Mara S. Zimmerman, Stephanie N. Schmidt, Charles C. Krueger, \\ M. Jake Vander Zanden, and Randy L. Eshenroder
}

\begin{abstract}
Resource polymorphisms are widely observed in fishes; however, ontogenetic contributions to morphological and ecological differences are poorly understood. This study examined whether ontogenetic changes in niche partitioning could explain morphological and buoyancy differences between lake trout (Salvelinus namaycush) morphotypes in Great Slave Lake (Northwest Territories, Canada). Morphometric analysis, buoyancy, capture depth, diet, and stable isotope data were used in concert to determine whether (i) differences occur in small, as well as large, lake trout, (ii) ontogenetic changes in morphology and buoyancy correlate with shifts in depth or diet, and (iii) a subset of small trout, putatively identified as "humpers", are distinct from other morphotypes. Ontogenetic changes in lake trout morphology were associated with an ecological shift between benthic and pelagic feeding. Resource partitioning between lean and siscowet-like trout occurred within benthic (small trout) and pelagic (large trout) habitats. The humper subset did not differ from small siscowet-like trout. By combining multiple methods and an ontogenetic perspective, our study provides novel perspectives on resource polymorphisms in large, deep lakes and on existing interpretations of stable isotope data from large lakes in general.
\end{abstract}

Résumé : Le polymorphisme des ressources est un phénomène fréquemment observé chez les poissons; cependant, les contributions ontogéniques aux différences morphologiques et écologiques restent mal comprises. Notre étude examine si les changements ontogéniques de partition de niche peuvent expliquer les différences de morphologie et de flottabilité entre les morphotypes de touladis dans le Grand Lac des Esclaves (Territoires du Nord-Ouest, Canada). Une analyse morphométrique, ainsi que des données sur la flottabilité, la profondeur de capture, le régime alimentaire et les isotopes stables, nous ont servi tout ensemble à déterminer $(i)$ si les différences se retrouvent à la fois chez les touladis de petite et de grande taille, (ii) s'il y a une corrélation entre les changements de morphologie et de flottabilité et les modifications de profondeur ou de régime alimentaire et (iii) si un sous-ensemble de touladis de petite taille, présumés être des « bossus », se distingue des autres morphotypes. Les changements ontologiques chez les touladis sont associés à une modification de l'alimentation, de benthique à pélagique. La partition des ressources entre les touladis maigres et les touladis d'allure siscowet se produit dans les habitats benthiques (petits touladis) et pélagiques (grands touladis). Le sous-ensemble des bossus ne diffère pas des petits touladis de type siscowet. En combinant plusieurs méthodes et utilisant une approche ontogénique, notre étude offre des perspectives inédites sur le polymorphisme des ressources dans des lacs profonds de grande taille et sur les interprétations actuelles des données d'isotopes stables dans les grands lacs en général.

[Traduit par la Rédaction]

\section{Introduction}

In recently deglaciated lakes, adaptive radiations of fishes are attributed to high intraspecific competition and open available niches (Robinson and Wilson 1994). Resource polymorphisms, defined as morphologically distinct "types" that use different resources in a water body (Skulason and Smith 1995), are maintained by ecological trade-offs associated with use of the different resources. Parallel patterns

Received 7 July 2008. Accepted 10 February 2009. Published on the NRC Research Press Web site at cjfas.nrc.ca on 5 June 2009. J20657

M.S. Zimmerman. ${ }^{\mathbf{1}}$ Washington Department of Fish and Wildlife, 600 Capitol Way N, Olympia, WA 98501, USA. S.N. Schmidt. St. Olaf College, Northfield, MN 55057, USA. C.C. Krueger and R.L. Eshenroder. Great Lakes Fishery Commission, Ann Arbor, MI 48105, USA.

M.J. Vander Zanden. Center for Limnology, University of Wisconsin-Madison, Madison, WI 53706, USA.

${ }^{1}$ Corresponding author (e-mail: mara.zimmerman@dfw.wa.gov). across water bodies or taxa draw attention to habitats where trade-offs likely occur, such as benthic and pelagic feeding niches (Schluter and McPhail 1993; Smith and Skulason 1996; Jastrebski and Robinson 2004). Alternately, ecological interactions can be examined within a lake with the goal of identifying mechanisms that maintain morphological and ecological differences (Schluter 1995; Svanback and Eklov 2003; Parsons and Robinson 2007). This study takes the latter approach and examines resource partitioning of coexisting lake trout (Salvelinus namaycush) morphotypes in Great Slave Lake, Northwest Territories.

Great Slave Lake is one of five North American lakes where lake trout are known to partition lake resources by habitat depth (Eshenroder 2008) and is less impacted by exploitation (Low et al. 1999; Evans 2000) and exotic species (Keleher 1972; Stewart 1997) than Lake Superior, which has been a focal lake for studying lake trout resource polymorphisms (Lawrie and Rahrer 1973; Moore and Bronte 2001; Harvey et al. 2003). Depths differ in ambient pressure, temperature, and light as well as prey available to lake trout 
(Eshenroder and Burnham-Curtis 1999; Janssen et al. 2007). Compared with shallow-water habitat $(<50 \mathrm{~m})$, deepwater habitats $(>50 \mathrm{~m})$ have low species diversity and are composed mainly of sculpins (Cottus sp., Myoxocephalus sp.), opossum shrimp (Mysis relicta), and deepwater ciscoes (Coregonus spp.; Eshenroder and Burnham-Curtis 1999). Deepwater lake trout morphotypes, the "humper" and "siscowet", are hypothesized to have adopted deepwater feeding strategies in response to density-dependent competition with an ancestral shallow-water (i.e., lean) morphotype (Eshenroder 2008). Siscowets undergo vertical migrations while feeding on deepwater ciscoes (Hrabik et al. 2006), assisted by their low buoyancy (high lipid) tissue (Henderson and Anderson 2002). Humper trout have received less ecological study than other morphotypes (Peck 1975; Zimmerman 2007), but may retain a planktivorous feeding habit throughout their life history (Eshenroder 2008). In comparison, lean trout are piscivorous, feeding in shallow waters below the thermocline (Van Oosten and Deason 1938; Dryer et al. 1965; Fisher and Swanson 1996).

The relationship between resource partitioning and ontogeny is a rarely examined aspect of resource polymorphisms, though an understanding of this relationship is likely to advance current understanding of morphotypic diversity (e.g., Parsons and Robinson 2007; Robinson et al. 2008). Depth partitioning is a broadly accepted difference among lake trout morphotypes; however, these results are primarily based on collections of large trout (Moore and Bronte 2001; Bronte et al. 2003; Zimmerman et al. 2006), and conclusions are biased toward the ecology of later life history stages. Small trout in monotypic lakes occupy deeper waters than large trout (Martin 1952; Elrod and Schneider 1987), suggesting that depth distributions also have an important ontogenetic component. Body form is correlated with ontogeny as well. Ontogenetic changes in siscowet morphology and buoyancy are as large as the difference between large siscowet and lean trout (Eschmeyer and Phillips 1965; Zimmerman et al. 2006). Therefore, lake trout ecology and morphology have the potential to be influenced by changes with size and age (i.e., ontogenic niche shifts) as well as interactions among morphotypes (i.e., resource partitioning).

A combined morphological and ecological comparison of small and large trout should disentangle within-morphotype niche shifts from among-morphotype resource partitioning. This type of comparison has been hampered by limited information on small trout, which are difficult to identify. In this study, we identify morphological groupings of small and large trout using geometric morphometrics, a statistically powerful tool for differentiating morphotypes based on shape differences (Bookstein 1991; Zelditch et al. 2004). Our morphometric analysis is complemented by analysis of habitat depth, buoyancy, diet, and stable isotopes. By combining these multiple sources of information, we test the hypothesis that ontogenetic shifts in niche partitioning explain differences in morphology and buoyancy observed among lake trout morphotypes. The study was conducted in the east arm of Great Slave Lake, where lean and siscowet-like morphotypes were previously identified based on morphological measures of large ( $>43 \mathrm{~cm}$ standard length (SL)) trout (Zimmerman et al. 2006). Recent sampling in Great Slave Lake included 15 putative humpers (Eshenroder
2008), whose morphology and ecology are quantitatively examined in this paper. The objectives were to $(i)$ determine whether morphological and buoyancy differences can be detected in small, as well as large, lake trout, (ii) investigate whether ontogenetic changes in lake trout morphology and buoyancy correlate with a shift in habitat depth or diet, and (iii) establish whether a subset of lake trout, identified as humper trout, were morphologically or ecologically distinct from the lean and siscowet-like morphotypes in Great Slave Lake.

\section{Materials and methods}

\section{Study system}

Great Slave Lake, Northwest Territories, is a deep, oligotrophic lake. The east arm of the lake lies in the Canadian Shield and is characterized by abundant deepwater habitat (maximum depth $=614 \mathrm{~m}$ ) and rocky substrate (Evans 2000). Lake trout were caught from the eastern arm (Christie Bay) during August of 2001, 2002, and 2005 with graded mesh gill nets $(64-114 \mathrm{~mm}$ stretch measure) set overnight for approximately $18 \mathrm{~h}$ and by angling with artificial lures (latitude and longitude coordinates for each set are available by request). Of 30 sets, 4 were in depths of 0 $50 \mathrm{~m}, 22$ were in $50-100 \mathrm{~m}$, and 4 were in $100-150 \mathrm{~m}$. All fish caught by angling were from water less than $30 \mathrm{~m}$ in depth. The shoreline has a steep grade; deepwater $(>50 \mathrm{~m})$ net sets were often within $100 \mathrm{~m}$ of shore.

While among the better studied of Canada's Great Lakes (Evans 2000), limited information has been published on Great Slave Lake's fish community. Similar to Lake Superior, the cold-water fish community of Great Slave Lake is composed of sculpins, ninespine stickleback (Pungitius pungitius), coregonines, burbot (Lota lota), and lake trout (Rawson 1951). Sculpin species include slimy sculpin (Cottus cognatus), spoonhead sculpin (Cottus ricei), and deepwater sculpin (Myoxocephalus thompsonii) (Rawson 1951; Keleher 1972; Stewart 1997). Both lakes have a shallow-water (cisco, Coregonus artedi) and deepwater pelagic coregonines (shortjaw cisco, Coregonus zenithicus) as well as lake whitefish (Coregonus clupeaformis). Two invertebrates, opossum shrimp (Mysis relicta) and a benthic amphipod (Diporeia affinis), are also abundant in the lake (Rawson 1953).

\section{Morphological groups}

The lateral image of each lake trout was captured in a full-body photograph (Zimmerman et al. 2006). Digital image files were used to quantify body shape and head shape with a series of digitized points classified as either landmarks or semilandmarks. Semilandmarks, though not homologous points, were useful to describe belly and head curvatures (Sampson et al. 1996; Langerhans et al. 2003). Body shape was measured using 16 landmarks and 4 semilandmarks (Fig. 1a) (Zimmerman et al. 2006, 2007). Head shape was measured with 3 landmarks and 20 semilandmarks; positioning of these landmarks was based on a grid that subdivided the area between the snout and the opercle into 10 equally spaced regions (Fig. $1 b$ ). A landmark-based geometric morphometric method was used to quantify body shape (Zelditch et al. 2004). This method represents shape 
Fig. 1. Landmarks (LM) used to measure lake trout (Salvelinus namaycush) shape. Body LM (a) were anterior tip of the snout (1), posterior tip of the maxilla (2), center of the eye (3), top of the cranium (4), posterior of neurocranium above top of opercle (5), anterior insertion of dorsal fin (6), posterior insertion of dorsal fin (7), anterior insertion of adipose fin (8), dorsal insertion of caudal fin (9), midpoint of hypural plate (10), ventral insertion of caudal fin (11), posterior insertion of anal fin (12), anterior insertion of anal fin (13), insertion point of pelvic fin (14), insertion point of pectoral fin (19), ventral surface of head below maxilla tip (20), and belly curvature at $20 \%, 30 \%, 40 \%$, and $50 \%$ of lake trout standard length (18-15, respectively). Head LM $(b)$ were the center of the eye (22), the posterior tip of the maxilla (23), and a division of the head profile into 10 evenly spaced partitions (1-21).

(a)
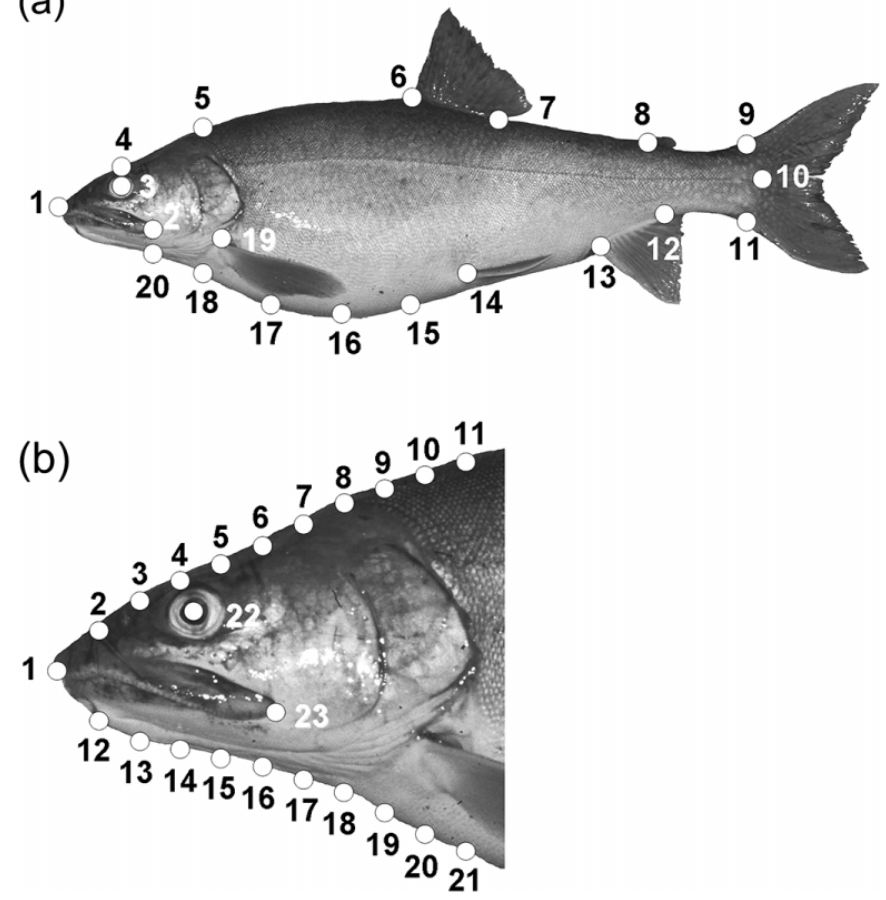

as partial warps that are calculated from digitized coordinates. Partial warps describe a set of shape deformations ( $2 k-4$, where $k$ is the number of landmarks); a biologically meaningful interpretation of partial warps is based on the composite shape difference between groups. Semilandmarks were adjusted using a "sliding" calculation (Zelditch et al. 2004; Zimmerman et al. 2007). Shape variables were standardized to mean size prior to analysis (Zimmerman et al. 2006). The $x, y$ coordinates were captured using tpsDIG software (life.bio.sunysb.edu/morph). Shape variables were calculated using CoordGen software, semilandmarks were adjusted using SemiLand software, and shape was sizestandardized using Standard6 software. CoordGen, SemiLand, and Standard6 are part of a series of Integrated Morphometric Programs (IMP) produced in MATLAB6 (MathWorks 2000) and used for morphometric analysis (www2.canisius.edu/ sheets/morphsoft.html).

Morphological groupings were identified from a modelbased cluster analysis (Fraley and Raftery 2006) using MCLUST v.3 software (www.stat.washington.edu/mclust). The models assumed an underlying Gaussian distribution of the data set. This method uses Bayesian information crite- rion to select the number of groups most likely to exist, assigns individuals to groups, and calculates the uncertainty of individual membership in a given group. Cluster analysis was performed separately for head and body shape data and was based on the first two principal components for each data set. Small $(<43 \mathrm{~cm} \mathrm{SL})$ and large $(>43 \mathrm{~cm}$ SL) size classes were analyzed separately. These size groupings were chosen a priori based on earlier results demonstrating that size standardization, necessary for further analyses, could not be performed if data from small and large lake trout were combined (Zimmerman et al. 2006).

Group assignments used in buoyancy and ecological comparisons were based on the model-based cluster results, with the exception of 15 individuals identified at the time of collection as humper trout. Identifying characteristics of humper trout were thin abdominal walls, eyes placed high on the head, and deep mid-body profiles. A priori assignments were used to evaluate the recently published assertion that a humper morphotype, distinct from the siscowet-like morphotype, exists in Great Slave Lake (Eshenroder 2008).

\section{Percent buoyancy}

Percent buoyancy was measured as weight in water divided by weight in air (Zimmerman et al. 2006). Fish were weighed to the nearest gram using a Pesola spring scale (Jennings 1989). Weights were taken in air and then in water. Prior to weighing in water, any remaining swim bladder gas was expelled via a longitudinal excision. The buoyancy measure accounts for all differences in soft and hard tissue that affect the specific gravity of lake trout tissue (Alexander 1972). As fat has lower specific gravity than water, tissue with high fat content will be lower in percent buoyancy.

An analysis of covariance (ANCOVA) tested whether buoyancy differed between morphotypes. Buoyancy was the response variable, morphotype the explanatory variable, and SL the covariate. Post hoc pairwise tests were conducted on the estimated marginal means. Estimated marginal mean values were adjusted for the effect of the covariate on buoyancy. Small and large size classes, defined by a threshold of $43 \mathrm{~cm}$ SL, were analyzed separately, as the buoyancy standard length relationship could not be linearized across all sizes. The same size threshold was used to assign small and large sizes classes in subsequent analyses.

\section{Habitat depth}

Mean depth for each net was calculated from nine evenly spaced bottom depth measures. Depth was recorded while nets were being set using a Lowrance X98DF sonar (50 kHz in deep water, $200 \mathrm{kHz}$ in shallow water). A twoway analysis of variance (ANOVA) tested whether depth of capture differed between small and large size classes of each morphotype. Interactions were examined with simple effect tests that compared the estimated marginal means of size classes within morphotype and morphotypes within size class. Capture depths of the humper group, which consisted solely of the small size class, were compared with small lean and siscowet trout using a one-way ANOVA.

\section{Diet analysis from stomach contents}

Stomachs were removed in the field and preserved in $10 \%$ 
formalin. Prey items were dissected from each stomach, sorted, and identified as terrestrial insects, opossum shrimp (Mysis relicta), benthic aquatic invertebrates, sculpins, and cisco. Prey from each stomach were enumerated and weighed by category. Data were reported for each morphotype as a percentage by occurrence, number, and weight. Identification of prey items was taxonomically coarse because of their partially digested condition. Parts and tissue that could not be identified were weighed separately. Wet weight was determined to the nearest one-hundredth of a gram after blotting surface water from each item. Lake trout stomachs were examined from the 2002 and 2005 collections.

A logistic regression tested whether the presence of sculpins and coregonids, the two major prey times identified in the diet analysis, could be predicted from the standard length of each morphotype.

\section{Stable isotope analysis}

Tissues for stable isotope analysis were collected in $\mathrm{Au}-$ gust 2005. Stoneflies $(n=7)$ and snails $(n=6)$, representative of a nearshore, littoral production base, were handpicked from overturned rocks and logs. Opossum shrimp ( $n=13$ ), representative of offshore, benthopelagic prey, were collected with a zooplankton net. Benthivorous lake whitefish $(n=1)$, planktivorous cisco $(n=7)$, and shortjaw cisco $(n=5)$ were collected simultaneously with the lake trout collections in graded-mesh gill nets. Grayling (Thymallus thymallus; $n=4$ ), representative of a littoral omnivore, were angled from the Stark River inlet into Great Slave Lake. Sculpins $(n=3)$ were dissected from the stomach of a lake trout caught in $90 \mathrm{~m}$ of water. Species-level identification of the sculpins was not possible because of their digested condition; however, the depth of capture suggests that these were deepwater sculpin. Sample sizes of lean, siscowet-like, and humper morphotypes in this analysis were 34, 31, and 15 fish, respectively. Morphotypes were identified based on known characteristics (Zimmerman et al. 2006) and were validated by this study (see Results).

Dorsal muscle tissue was taken from all fish species except grayling, where pectoral fin clips were collected. Soft tissue was extracted from snail shells; other invertebrates were analyzed in their entirety. Tissues were frozen at the time of collection and subsequently oven-dried to remove moisture $\left(60{ }^{\circ} \mathrm{C}, 3\right.$ days $)$. Approximately $1.0 \mathrm{mg}( \pm 0.3 \mathrm{mg})$ of tissue was packed into $5 \mathrm{~mm} \times 8 \mathrm{~mm}$ tin capsules for sample analysis. Carbon $\left(\delta^{13} \mathrm{C}\right)$ and nitrogen $\left(\delta^{15} \mathrm{~N}\right)$ isotopes were analyzed at the University of California-Davis Stable Isotope Facility on a Europa Hydra 20/20 continuous-flow isotope-ratio mass spectrometer. Isotopes are reported as $\delta$ values representing a deviation in parts per thousand (\%o) from a standard; $\delta^{13} \mathrm{C}$ or $\delta^{15} \mathrm{~N}=\left(\left[R_{\text {sample }} / R_{\text {standard }}\right]-1\right) \times$ 1000 , where $R={ }^{13} \mathrm{C} /{ }^{12} \mathrm{C}$ or ${ }^{15} \mathrm{~N} /{ }^{14} \mathrm{~N}$. Standard material was Pee Dee belemnite limestone for $\delta^{13} \mathrm{C}$ and atmospheric nitrogen for $\delta^{15} \mathrm{~N}$. More positive isotope values (less negative for carbon) indicated a higher proportion of the heavy isotope $\left({ }^{13} \mathrm{C}\right.$ or $\left.{ }^{15} \mathrm{~N}\right)$ in the sample. Seven percent of the samples were analyzed in duplicate; one standard error of the mean for replicates was $0.24 \%$ for $\delta^{13} \mathrm{C}$ and $0.13 \%$ for $\delta^{15} \mathrm{~N}$.

To account for the variability in carbon signature due to lipid content (Kiljunen et al. 2006), lipids were extracted from a subset $(n=48)$ of fish tissue samples using a modified Folch method (Sweeting et al. 2006), and $\delta^{13} \mathrm{C}$ was reanalyzed. Tissue was homogenized in a 2:1 chloroformmethanol mixture and sonicated. Samples were then centrifuged to separate the remaining tissue and the supernatant was removed. Samples were washed with ultra-pure water, sonicated, and centrifuged once more. The remaining tissue was oven-dried at $60{ }^{\circ} \mathrm{C}$ for $24 \mathrm{~h}$. Lipid content was the weight difference prior and subsequent to the extraction, expressed as a proportion of the weight of the original tissue sample.

$\delta^{13} \mathrm{C}$ values were compared between lipid-extracted samples and bulk tissue samples. The difference $(\Delta)$ in $\delta^{13} \mathrm{C}$ was calculated for each sample as $\Delta \delta^{13} \mathrm{C}=\delta^{13} \mathrm{C}_{\text {lipid-extracted }}$ $\delta^{13} \mathrm{C}_{\text {bulk }}$. A nonlinear relationship existed between $\Delta \delta^{13} \mathrm{C}$ and $\mathrm{C}: \mathrm{N}$ ratio of untreated samples, which closely resembled the Kiljunen et al. (2006) model. To improve the fit, we re-estimated the parameters $D$ (difference in $\delta^{13} \mathrm{C}$ between protein and lipids) and $I$ (a constant) by iteratively fitting the Kiljunen et al. (2006) model to our observed data until the sum of squared errors was minimized. Our model slightly improved the fit $\left(R^{2}=0.94, F_{[1,46]}=720.74, p<0.0001\right)$ and resulted in a relationship between the observed and modelpredicted $\Delta \delta^{13} \mathrm{C}$ that was not significantly different than a $1: 1$ relationship (95\% confidence interval of the slope of the best fit regression line was 0.87 to 1.01 ). Modeling efficiency (Mayer and Butler 1993), a goodness-of-fit measure ( 1 = perfect fit, $0=$ poor model performance), improved from 0.60 using the Kiljunen parameters to 0.87 for our recalculated parameters. Therefore, the revised model was used to normalize untreated samples for lipid content:

$$
\delta^{13} C^{\prime}=\delta^{13} \mathrm{C}+5.195\{0.074+[3.9 /(1+287 / L)]\}
$$

where $\delta^{13} \mathrm{C}^{\prime}$ is the lipid-corrected value of the sample; $\delta^{13} \mathrm{C}$ is the observed untreated value of the sample; and $L$ is the proportional lipid content of the sample calculated by

$$
L=93 /\left\{1+[(0.246 \times \mathrm{C}: \mathrm{N})-0.775]^{-1}\right\}
$$

Separate two-way ANOVAs tested whether the lipid-corrected $\delta^{13} \mathrm{C}$ (hereafter $\delta^{13} \mathrm{C}$ refers to the lipid-corrected value) and $\delta^{15} \mathrm{~N}$ differed between size classes and among morphotypes. To test whether an ontogenetic change in isotope values existed, the estimated marginal means for each size class were compared within morphotypes (i.e., simple effects test). As the humper group consisted only of small trout, a one-way ANOVA was used to examine whether humper trout differed from small lean and siscowetlike trout.

Unless specifically mentioned, data were analyzed using SPSS version 12.0 (SPSS 2003). Data were inspected for outliers and tested for normality (Kolmogorov-Smirnov) and variance homogeneity (Levene's test). Results were considered significant when $p<0.05$.

\section{Results}

A total of 217 lake trout were analyzed. Fifty-nine of these lake trout $(28-71 \mathrm{~cm} \mathrm{SL})$ were caught in the $0-50 \mathrm{~m}$ depth strata (mean, range: 10, 4-43 trout per set) and included 13 angled fish. Another 155 lake trout $(26-73 \mathrm{~cm}$ SL) were caught in the 50-100 m strata (7, 2-29 trout per 
Fig. 2. Morphological groupings of individual lake trout (Salvelinus namaycush) in Great Slave Lake based on body shape of small (a) and large $(c)$ lake trout and head shape of small $(b)$ and large $(d)$ lake trout. Axes are the first two principal components (PC) calculated from each data set; percentages represent variation explained by that component. Outlines indicate the shape variation represented by each axis and were drawn from vector plots produced in PCAGen. Group 1 fish resemble the siscowet-like morphotype (open squares), and Group 2 fish resemble the lean morphotype (solid triangles). Asterisks (*) overlaying open squares indicate individuals assigned a priori as humper trout. Ellipse centers are mean scores, and ellipses indicate one standard deviation for each group.

(a)

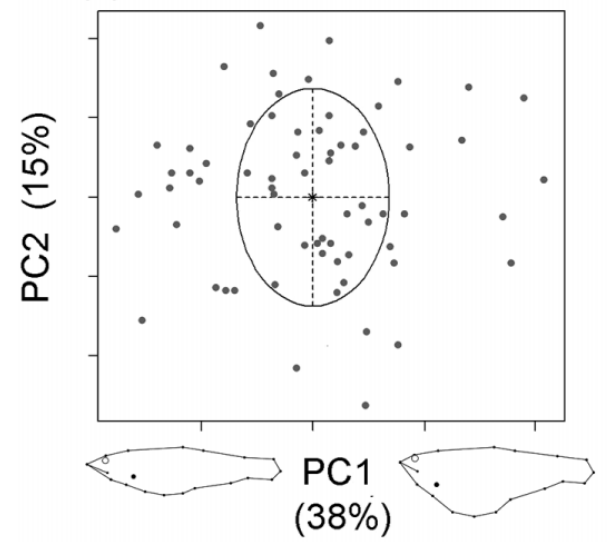

(b)

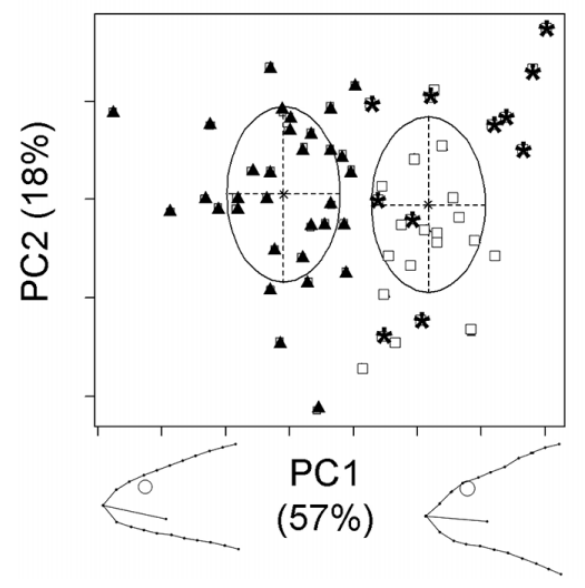

set). The remaining 3 lake trout (29-51 cm SL) were caught in the $100-150 \mathrm{~m}$ stratum $(1,0-2$ trout per set).

\section{Morphology and buoyancy of small and large lake trout}

For small lake trout, two groups were most likely present based on head shape measures, but only one group was most likely present based on body shape (Figs. $2 a, 2 b$ ). For large lake trout, two groups were identified as being most likely present based on both head and body shape data (Figs. $2 c$, $2 d$ ). Head shape of Group 1 (siscowet-like) had a shorter snout, eye higher on the head, and deeper posterior head region than Group 2 (lean) (Figs. 2b, 2d). Body shape of Group 1 included a shorter head, deeper mid-body, and thicker caudal peduncle than Group 2 (Fig. 2c). Although small lake trout did not group by body shape, the major axis of body shape variation was similar between small and large lake trout (Figs. 2a, 2c).

Morphotype assignments used in subsequent analyses were based on the above morphological groupings and are hereafter referred to as lean and siscowet-like. Group iden- (c)

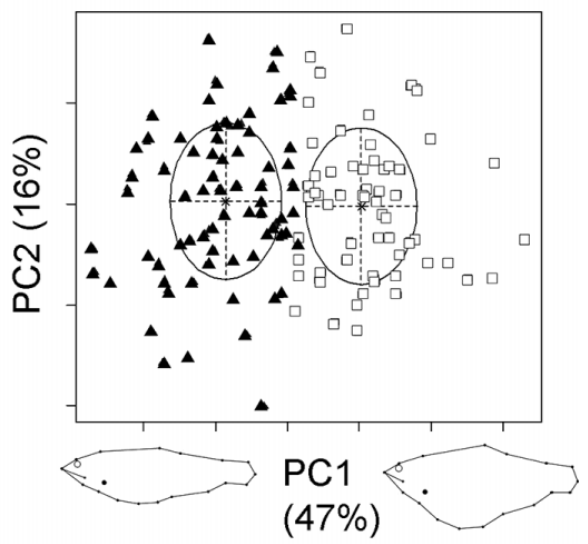

(d)

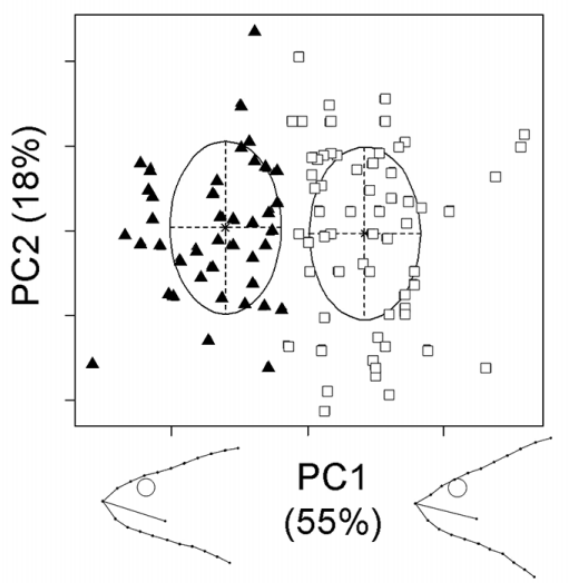

tities in this study corresponded well with the lean and siscowet-like groups identified from a previous analysis on a subset of these data (Zimmerman et al. 2006; 100\% correspondence for individuals classified with less than $10 \%$ uncertainty). Small lake trout were included in subsequent analyses if the uncertainty associated with their head grouping was less than $10 \%$, and large lake trout were included if their group assignment was the same for head and body data or if the uncertainty of a group assignment was less than $10 \%$. Correspondence between head and body groupings for large lake trout was high (98\% for individuals classified with less than $10 \%$ uncertainty). Comparisons of the humper group with the lean and siscowetlike groups are presented last.

Percent buoyancy of siscowet-like trout was lower than that of lean trout in both the small (mean \pm 1 standard error (SE), lean $6.1 \% \pm 0.15 \%$, siscowet-like $5.4 \% \pm 0.19 \%$, $F_{[2,39]}=4.01, p=0.03$ ) and large size classes (lean $5.3 \% \pm$ $0.15 \%$; siscowet-like $2.7 \% \pm 0.15 \% ; F_{[1,104]}=152.0, p<$ 0.001 ). The intermorphotype difference in buoyancy was 
Fig. 3. Lake trout (Salvelinus namaycush) buoyancy as a function of standard length in Great Slave Lake. Lean (solid triangles), siscowet-like (open squares), and humper (gray circles) morphotypes are plotted separately.

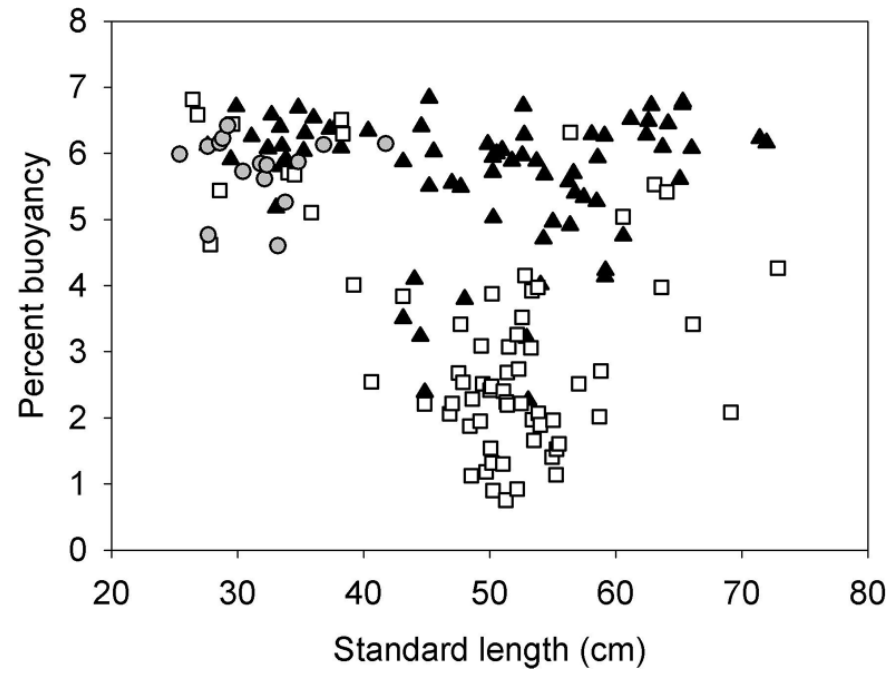

three times greater in large than in small trout (Fig. 3). For small lake trout, siscowet-like trout buoyancies decreased with increasing length, but lean buoyancies were not associated with length (ANCOVA, morphotype by SL interaction, $\left.F_{[2,39]}=5.7, p=0.007\right)$.

\section{Ontogenetic changes in capture depth and diet}

Capture depths of small and large lake trout differed among morphotypes (morphotype by size interaction, $F_{[1,137]}=6.4, p=0.01$, Fig. 4). Large siscowet-like trout were caught in deeper water than large lean trout (simple effect, $p<0.001$ ) but in similar depths as small siscowet-like trout (simple effect, $p=0.41$ ). Small lean trout were also caught in deeper water than large lean trout (simple effect, $p=0.003$ ). Capture depth of small siscowet-like trout did not differ from small lean trout (simple effect, $p=0.47$ ).

Lake trout were primarily piscivorous; $68 \%$ of all stomachs contained fish. Lean and siscowet-like trout both consumed sculpins and coregonines (Table 1), although stomach data indicated that several large lean trout had specialized on terrestrial insects, and one small siscowet-like trout specialized on benthic invertebrates. Occurrence and weight of coregonine prey increased between the small and large size classes of lean and siscowet-like trout. Mysis relicta and aquatic benthic invertebrates were found in lake trout stomachs but were not common. Terrestrial insects included Coleoptera, Diptera, and Hymenoptera. Aquatic invertebrates included Chironomidae larvae, aquatic Coleoptera, and Trichoptera pupae. Sculpins were mainly deepwater sculpin.

Probability of the presence of sculpins decreased (Wald's $=4.9$, df $=1, p=0.03$ ) and the probability of cisco increased (Wald's $=4.3$, df $=1, p=0.04$ ) with increasing SL of lean trout. However, presence of sculpin and cisco could not be predicted by the SLs of siscowet-like trout (sculpins, Wald's $=0.001, \mathrm{df}=1, p=0.98$; cisco, Wald's $=$ 1.56, df $=1, p=0.2$ ).

Lake trout were the most enriched in $\delta^{15} \mathrm{~N}$ of any species
Fig. 4. Capture depths of small $(<43 \mathrm{~cm}$ standard length, SL) and large $(>43 \mathrm{~cm}$ SL) lake trout (Salvelinus namaycush) in Great Slave Lake. Lean (solid), siscowet-like (hatched), and humper (gray) morphotypes are shown separately. Data are means and standard errors. Letters (A, B, C) represent statistically different pairwise comparisons $(\alpha=0.05)$.

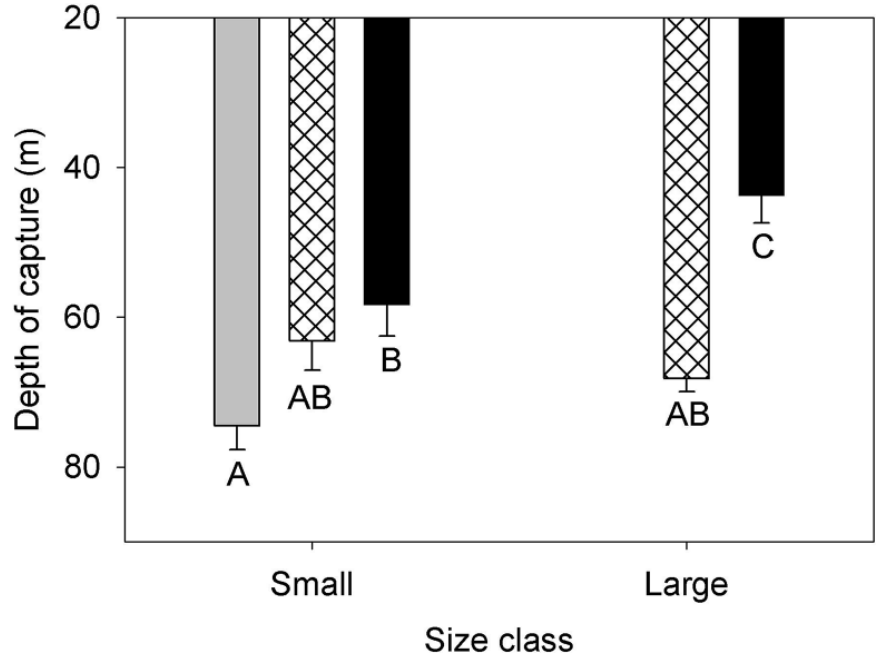

sampled from Great Slave Lake (Fig. 5). From lowest to highest, trophic levels included primary consumers (i.e., snails, stoneflies), megazooplankton (Mysis relicta), planktivoresbenthivores (ciscoes and lake whitefish), and piscivores (lake trout). Taxa that typically feed in nearshore, littoral habitats (i.e., stoneflies, snails, lake whitefish, grayling) were enriched in $\delta^{13} \mathrm{C}$. Taxa that typically feed in offshore or profundal habitats (lake trout, sculpins, ciscoes, Mysis relicta) were more depleted in $\delta^{13} \mathrm{C}$. Shortjaw cisco were slightly more enriched in $\delta^{13} \mathrm{C}$ than cisco.

Large lean trout were depleted in $\delta^{15} \mathrm{~N}$ compared with small lean trout, whereas large and small siscowet-like trout had similar $\delta^{15} \mathrm{~N}$ values (morphotype by size interaction, $\delta^{15} \mathrm{~N}, F_{[1,60]}=4.08, p=0.05$, Fig. 6). When compared with siscowet-like trout (both size classes), lean trout in both size classes were depleted in $\delta^{15} \mathrm{~N}$ (morphotype effect, $\delta^{15} \mathrm{~N}$, $\left.F_{[1,60]}=3.88, p=0.05\right)$. Large trout were depleted in $\delta^{13} \mathrm{C}$ relative to small trout (size effect, $\delta^{13} \mathrm{C}, F_{[1,60]}=16.03, p<$ $0.001)$; this effect was consistent for lean and siscowet-like trout (morphotype by size interaction, $\delta^{13} \mathrm{C}, F_{[1,60]}=1.04, p=$ $0.31)$. Lean trout were also depleted in $\delta^{13} \mathrm{C}$ compared with siscowet-like trout (morphotype effect, $\delta^{13} \mathrm{C}, F_{[1,60]}=3.98$, $p=0.05$ ); however, this difference was slight and not significant within size class (simple effects, $\delta^{13} \mathrm{C}$, small: $p=$ 0.08; large: $p=0.38$, Fig. 6). One outlier, a $95 \mathrm{~cm} \mathrm{SL}$ lean trout, was removed prior to the analysis; the $\delta^{13} \mathrm{C}$ and $\delta^{15} \mathrm{~N}$ values of this large trout were greater than 3 standard deviations from the mean values for the lean morphotype.

\section{Distinctiveness of humper trout}

Morphological, buoyancy, and ecological characteristics of the humper group were similar to small siscowet-like trout and differed from small lean trout. All 15 humper trout were in the small size class; 11 were classified in Group 1 (siscowet-like) and the morphology of the remaining four was not analyzed because of poor layout in the digital image. Capture depths and buoyancy (mean $\pm 1 \mathrm{SE}, 5.5 \% \pm$ 
Table 1. Diet composition of small ( $<43 \mathrm{~cm}$ standard length, SL) and large ( $>43 \mathrm{~cm}$ SL) lean, siscowet-like, and humper lake trout (Salvelinus namaycush) collected in August 2002 and 2005 from Great Slave Lake.

\begin{tabular}{|c|c|c|c|c|c|c|}
\hline Morphotype & $\begin{array}{l}\text { Size } \\
\text { class }\end{array}$ & $N$ & Prey item & $\%$ occurrence & $\%$ by number & $\%$ by weight \\
\hline \multirow[t]{10}{*}{ Lean } & \multirow[t]{5}{*}{ Small } & \multirow[t]{5}{*}{10} & Terrestrial insect & 22.2 & 7.7 & 0.1 \\
\hline & & & Mysis & 0.0 & 0.0 & 0.0 \\
\hline & & & Benthic invertebrate & 0.0 & 0.0 & 0.0 \\
\hline & & & Sculpin & 55.6 & 76.9 & 16.5 \\
\hline & & & Coregonine & 22.2 & 15.4 & 83.8 \\
\hline & \multirow[t]{5}{*}{ Large } & \multirow[t]{5}{*}{26} & Terrestrial insect & 12.5 & 64.4 & 0.4 \\
\hline & & & Mysis & 3.1 & 1.2 & 0.0 \\
\hline & & & Benthic invertebrate & 12.5 & 6.5 & 0.0 \\
\hline & & & Sculpin & 28.1 & 16.2 & 6.4 \\
\hline & & & Coregonine & 43.8 & 11.7 & 93.1 \\
\hline \multirow[t]{10}{*}{ Siscowet-like } & \multirow[t]{5}{*}{ Small } & \multirow[t]{5}{*}{10} & Terrestrial insect & 9.1 & 23.2 & 2.6 \\
\hline & & & Mysis & 18.2 & 7.0 & 0.2 \\
\hline & & & Benthic invertebrate & 18.2 & 51.1 & 4.0 \\
\hline & & & Sculpin & 36.4 & 14.0 & 25.4 \\
\hline & & & Coregonine & 18.2 & 4.7 & 68.2 \\
\hline & \multirow[t]{5}{*}{ Large } & \multirow[t]{5}{*}{37} & Terrestrial insect & 16.1 & 7.6 & 0.4 \\
\hline & & & Mysis & 12.9 & 8.7 & 0.0 \\
\hline & & & Benthic invertebrate & 6.5 & 1.1 & 0.1 \\
\hline & & & Sculpin & 35.5 & 40.2 & 10.5 \\
\hline & & & Coregonine & 29.0 & 42.4 & 88.9 \\
\hline \multirow[t]{5}{*}{ Humper } & \multirow[t]{5}{*}{ Small } & \multirow[t]{5}{*}{13} & Terrestrial insect & 6.3 & 25.9 & 4.1 \\
\hline & & & Mysis & 12.5 & 7.4 & 0.0 \\
\hline & & & Benthic invertebrate & 12.5 & 5.6 & 0.0 \\
\hline & & & Sculpin & 62.4 & 44.4 & 56.8 \\
\hline & & & Coregonine & 6.3 & 16.7 & 39.1 \\
\hline
\end{tabular}

Fig. 5. Stable isotope values for the Great Slave Lake food web: herbivores (snails and stoneflies), megazooplankton (Mysis relicta), planktivores (ciscoes), benthivores (lake whitefish, sculpins), and piscivores (lake trout). Lake trout (Salvelinus namaycush) are partitioned into three morphological groups (lean, solid triangle; siscowet, open square; humper, open circle). Data for lake trout and lower trophic levels (gray diamonds) are means and one standard error. Lake trout data are estimated marginal means evaluated at a standard length of $45.8 \mathrm{~cm}$.

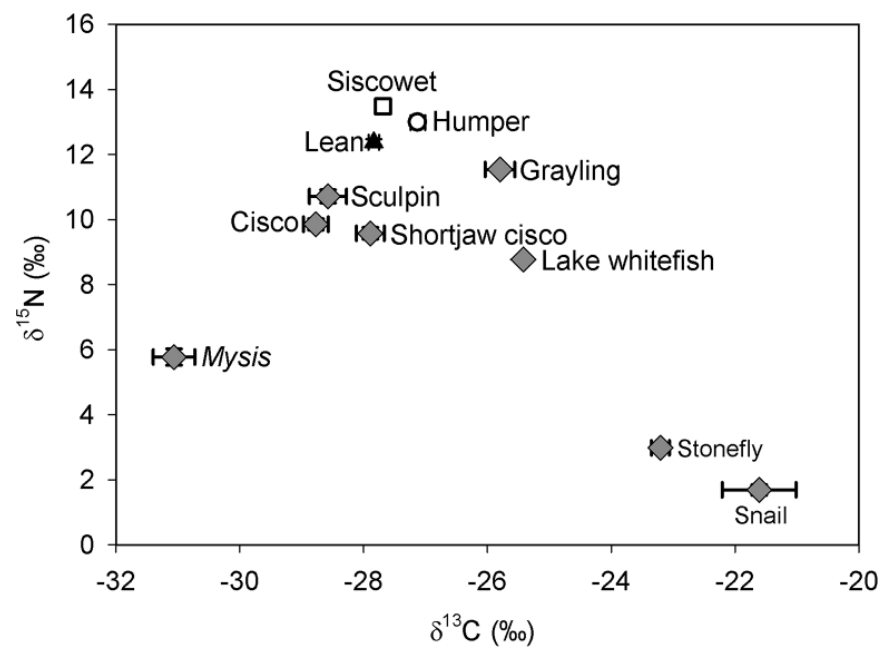

$0.36 \%$ ) of humper trout did not differ from small siscowetlike trout (pairwise tests, depth: $p=0.42$; buoyancy: $p=$ 0.80, Figs. 3, 4); however, humpers were caught slightly deeper, but had comparable buoyancies, than small lean trout (pairwise tests, depth: $p=0.006$; buoyancy: $p=0.11$ ). The $\delta^{15} \mathrm{~N}$ and $\delta^{13} \mathrm{C}$ of the humper group did not differ from small siscowet-like trout (pairwise test, $\delta^{13} \mathrm{C}, p=0.10 ; \delta^{15} \mathrm{~N}$, $p=0.34$, Fig. 6); however, humpers were more enriched in $\delta^{15} \mathrm{~N}$ and $\delta^{13} \mathrm{C}$ when compared with small lean trout (pairwise test, $\left.\delta^{13} \mathrm{C}, p=0.01 ; \delta^{15} \mathrm{~N}, p=0.02\right)$. Sculpins were the dominant prey item by occurrence, number, and weight in humper stomachs (Table 1); however, the presence of sculpins (Wald's $=0.08$, df $=1, p=0.78$ ) and ciscoes (Wald's = $0.0, \mathrm{df}=1, p=0.99$ ) could not be predicted from humper SL.

\section{Discussion}

An ontogenetic perspective to lake trout resource partitioning in Great Slave Lake provided insights into lake trout morphotypic diversity not evident from comparisons of large trout alone. For example, morphological and ecological differences occurred within and between size classes of lake trout morphotypes. Differences previously noted between large lean and siscowet-like trout in Great Slave Lake and Lake Superior (e.g., habitat depth, body shape, and buoyancy; Khan and Qadri 1970; Moore and Bronte 2001; Zimmerman et al. 2006) were found to be associated with pelagic feeding. In comparison, small lean and siscowet-like trout in Great Slave Lake differed most notably in head 
Fig. 6. Ontogenetic changes in stable isotope composition of lean (solid bars), siscowet-like (hatched bars), and humper (gray bars) lake trout (Salvelinus namaycush) in Great Slave Lake. $\delta^{15} \mathrm{~N}(a)$ and $\delta^{13} \mathrm{C}(b)$ are shown for small $(<43 \mathrm{~cm}$ standard length, $\mathrm{SL})$ and large $(>43 \mathrm{~cm} \mathrm{SL})$ lake trout of each morphotype. Data are means and standard errors. Letters $(\mathrm{X}, \mathrm{Y}, \mathrm{Z})$ represent statistically different pairwise comparisons $(\alpha=0.05)$. Note that siscowet-like trout of both sizes combined are significantly enriched in $\delta^{13} \mathrm{C}$ compared with lean trout (main effect).
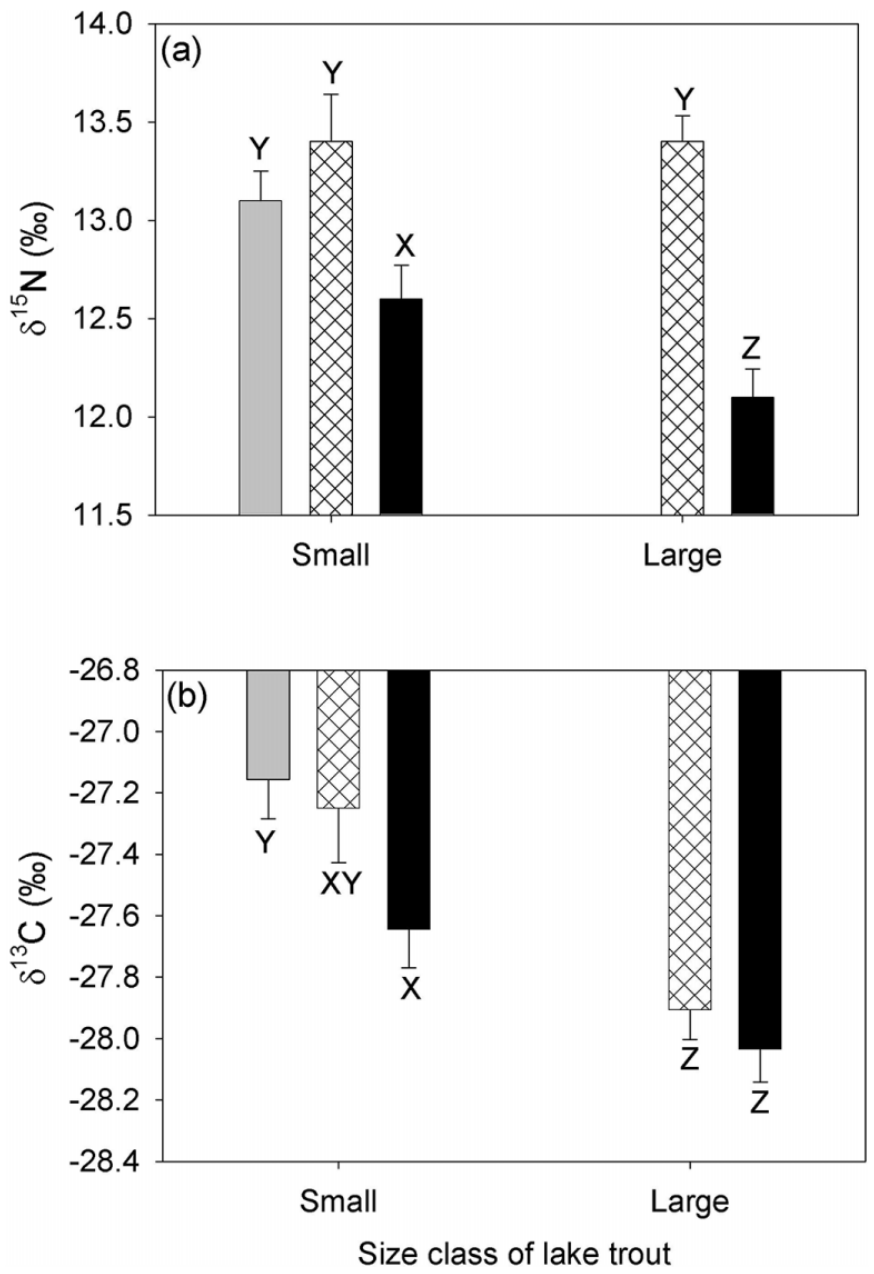

shape and fed in deep, benthic habitats (objective $i$ ). Small siscowet-like trout had deeper head profiles, blunter snouts, and eyes higher on their heads than small lean trout. Furthermore, resource partitioning between lake trout morphotypes in Great Slave Lake occurred within, not between, benthic (small trout) and pelagic (large trout) habitats (objective ii). Finally, evaluating size-comparable individuals of each morphotype revealed that individuals previously designated as humpers were not distinguishable from siscowet-like trout (objective iii), a result supported by four independent measures (i.e., shape, buoyancy, depth, stable isotopes).

\section{Ontogenetic niche shifts and resource partitioning}

Ontogenetic correlations in the morphology and ecology of lake trout expands existing paradigms on the role of resource partitioning in maintaining morphotypic diversity (Schluter and McPhail 1993; Robinson and Wilson 1994; Skulason and Smith 1995). For example, the existing para- digm for fishes in recently deglaciated lakes has focused on benthic (littoral) versus pelagic (limnetic) feeding niches. Lake trout use benthic and pelagic niches; however, based on our study, resource partitioning between lake trout morphotypes occurs within, not between, benthic (small trout) and pelagic (large trout) habitats. Different ecological tradeoffs are likely to contribute to the ontogenetic niche shift from benthic to pelagic feeding we observed in lake trout morphotypes, as opposed to benthic versus pelagic niche partitioning at comparable ontogenetic stages, as observed in other species pairs such as threespine stickleback (Gasterosteus aculeatus; Schluter and McPhail 1992; Schluter 1995) and pumpkinseed (Lepomis gibbosus; Robinson et al. 1993; Ackermann and Cheverud 2004; Jastrebski and Robinson 2004). Ontogenetic niche shifts in fishes are typically explained with respect to predation risk and gape limitation (Werner and Hall 1988; Hjelm et al. 2000; Ward-Campbell and Beamish 2005), whereas resource polymorphisms are typically explained by differences in feeding efficiency and competitive ability (Schluter 1995; Svanback and Eklov 2004; Parsons and Robinson 2007).

In Great Slave Lake, lean and siscowet-like trout shifted from benthic to pelagic feeding with increased body size as evidenced by the depletion in the $\delta^{13} \mathrm{C}$ signature between small and large lake trout. Pelagic carbon sources (e.g., phytoplankton) are depleted in $\delta^{13} \mathrm{C}$ compared with sources of benthic carbon (e.g., macrophytes; Hecky and Hesslein 1995; Vander Zanden and Rasmussen 1999). Diet data from lean trout also demonstrated an increased prevalence of ciscoes in the stomachs of large lake trout, and a similar yet nonsignificant trend in the consumption of ciscoes was observed for siscowet-like trout. A benthic to pelagic feeding shift was previously noted for lake trout between 40 and $49 \mathrm{~cm}$ SL in Lakes Superior and Michigan (Van Oosten and Deason 1938; Dryer et al. 1965; Fisher and Swanson 1996), a size range that corresponds well with results from Great Slave Lake.

Based on data from this study, our conceptual model for resource partitioning of lake trout morphotypes is as follows. Small lake trout are benthic feeders that overlap in depth distributions but partition trophic resources within this habitat. Around $43 \mathrm{~cm}$ SL, rapid morphological and buoyancy diversification accompanies a shift to pelagic feeding in both lean and siscowet-like trout. Lean trout transition to pelagic feeding by moving to more shallow depths. In contrast, siscowet-like trout transition to pelagic feeding over the same bottom depths and undergo pronounced changes in fat accumulation and in mid-body profile facilitating diel vertical migration (Hrabik et al. 2006).

Although resource partitioning was most notable in large lake trout, small lean and siscowet-like trout also differed morphologically and ecologically. Small lake trout partitioned trophic resources, as evidenced by different $\delta^{15} \mathrm{~N}$ signatures, while overlapping in depth distributions. In this respect, small lake trout differed from other examples of benthic resource partitioning where species or morphotypes occupy different depth zones (e.g., Arctic char (Salvelinus alpinus) or lake whitefish; O'Connell et al. 2005; Power et al. 2005; Kennedy et al. 2006). The $\delta^{15} \mathrm{~N}$ difference between small lean and siscowet-like trout (1\%o) was minimal and not likely to reflect feeding at different trophic levels, but 
may represent differential use of sculpins, small coregonines, and invertebrate prey within deepwater benthic habitats. One explanation for the $\delta^{15} \mathrm{~N}$ results is that small siscowet-like trout specialize on sculpin prey that are more enriched $\delta^{15} \mathrm{~N}$ than small coregonines or benthic invertebrates. To further resolve the relationship between morphology and ecology in small lake trout, future study should focus on the functional importance of head shapes related to prey types consumed by small lake trout.

Depth stratification of large lake trout was associated with different pelagic feeding strategies for each morphotype. Specifically, diel vertical migration is a characteristic behavior of siscowet but not of lean trout (Eshenroder and Burnham-Curtis 1999; Hrabik et al. 2006). Diel vertical migration connects three trophic levels of the deepwater pelagic food web including Mysis relicta, pelagic coregonines, and lake trout. High fat content of siscowets improves buoyancy regulation by reducing reliance on swim bladder inflation as a buoyancy-control mechanism during rapid ascents or descents (Alexander 1972, 1993; Henderson and Anderson 2002). A trade-off may occur between lipid accumulation and feeding performance of lake trout at different depths. High-fat tissue should offer a competitive advantage for pelagic feeding in deepwater habitats, where prey abundances are low but available prey (i.e., deepwater coregonines) are high in fat. In comparison, low-fat tissue may be an advantage in shallow-water habitats, where prey abundances are high but available pelagic prey (i.e., cisco) are low in fat.

Depth partitioning of pelagic habitat is also observed for pelagic coregonines (Koelz 1927; Smith and Todd 1984; Eshenroder et al. 1999), a major prey item for lake trout. Therefore, lean and siscowet-like trout in Great Slave Lake are likely consuming different coregonine species. Unfortunately, we did not have an adequate sample size to compare depth distributions of the two pelagic coregonines, cisco and shortjaw cisco, present in Great Slave Lake, and the digested state of most stomach samples obscured species-level identification in lake trout diets. However, cisco and shortjaw cisco are known to stratify by depth in the Laurentian Great Lakes (Koelz 1927; Smith 1964), suggesting a similar pattern of depth partitioning exists in Great Slave Lake.

\section{Are humper lake trout morphologically or ecologically distinct?}

The ability to morphologically distinguish small lean and siscowet-like trout in Great Slave Lake provided a valuable comparison for the humper individuals, as all humper trout in our study occurred in the small size class. Small size is a characteristic of humpers in Lake Superior, which grow slowly and mature at small sizes (Rahrer 1965; BurnhamCurtis and Bronte 1996; Zimmerman et al. 2007). Analysis of comparable size ranges avoids confounding effects of ontogenetic shape change and actual morphotypic differences on the study results.

This study did not support the existence of a third lake trout morphotype, the humper, in Great Slave Lake. While a thin abdominal wall remains an identifying feature of humpers, these lake trout were not morphologically distinct from small siscowet-like trout with respect to body or head shape. In addition, the ecology of the humper individuals was not planktivorous but rather characterized by deepwater benthic feeding also observed in small siscowet-like trout.

Our results further evaluate an existing hypothesis of lake trout differentiation in large, deep North American lakes (Eshenroder 2008), which proposed that humpers are a deepwater ancestor of fatty, vertically migrating siscowet morphotype. The basis of this argument was the notion of a more frequent presence of the humper morphotype than the siscowet morphotype and the presence of a humper morphotype in both of the lakes where siscowets were known to occur (Lake Superior and Great Slave Lake). At present, morphological and ecological data from Great Slave Lake do not substantiate the assignment of a third morphotype; however, this result may be modified by further analysis of life history or genetic data of available collections or by further sampling of the lake. As a result, the hypothesis on lake trout differentiation should be revisited, an endeavor most appropriately accomplished by a quantitative, cross-lake comparison of lake trout morphology, ecology, and genetics.

\section{Insights into stable isotope analysis from the Great Slave Lake food web}

Stable isotope analysis provides a valuable tool in the study of food webs (Post 2002; Sierszen et al. 2006; Schmidt et al. 2007). Our stable isotope analysis of Great Slave Lake highlights some interesting patterns that are relevant for the interpretation of stable isotope data from large lakes in general. Many aspects of the Great Slave Lake food web are comparable with Lake Superior, which provides a reasonable comparison of isotopic signatures and their interpretation. In both lakes, distinct trophic levels, in the form of an enriched $\delta^{15} \mathrm{~N}$ signature, were occupied by herbivores, planktivorous plankton (i.e., Mysis relicta), planktivorous and benthivorous fishes (i.e., coregonines and sculpins), and piscivores (i.e., lake trout) (Harvey and Kitchell 2000; Schmidt 2008). Siscowet trout were consistently more enriched in $\delta^{15} \mathrm{~N}$ than lean trout in both lakes (Harvey et al. 2003). Distinct nearshore (enriched $\delta^{13} \mathrm{C}$ ) and offshore (depleted $\delta^{13} \mathrm{C}$ ) isotope signatures were observed in the lower trophic levels in each lake. Similar to observations from a broad spectrum of lakes, the range of $\delta^{13} \mathrm{C}$ signatures become dampened at higher trophic levels (Hecky and Hesslein 1995; Vander Zanden and Vadeboncoeur 2002).

In Great Slave Lake, $\delta^{15} \mathrm{~N}$ decreased as body size of lean lake trout increased. This finding contrasts with the general expectation that trophic position will gradually increase as a function of size and age. An ontogenetic shift from feeding on sculpins (higher $\delta^{15} \mathrm{~N}$ ) to coregonines (lower $\delta^{15} \mathrm{~N}$ ) may have produced the $\delta^{15} \mathrm{~N}$ result and has also been observed in Twelve Mile Lake, Ontario (Vander Zanden et al. 2000). $\delta^{15} \mathrm{~N}$ differences between sculpins and coregonines can be explained by differences in their diet. Deepwater sculpin consume primarily Diporeia, supplemented with Mysis (Selgeby 1988), whereas coregonines have a diet high in Mysis, supplemented by $\delta^{15} \mathrm{~N}$-depleted copepods (Anderson and Smith 1971; Harvey and Kitchell 2000). Although a shift in prey type is plausible for lean trout, the lack of an ontogenetic $\delta^{15} \mathrm{~N}$ shift for the siscowet-like morphotype indicates that feeding depth, as well as prey type, may have contributed to ontogenetic changes in the lean morphotype $\delta^{15} \mathrm{~N}$ signatures. $\delta^{15} \mathrm{~N}$ enrichment with depth has been demon- 
strated for Diporeia in Lake Superior (Sierszen et al. 2006) and was attributed to isotopic fractionation of nitrogen isotopes during particle settling and decomposition (Saino and Hattori 1980; Sierszen et al. 2006). Results from our study are consistent with depth-related isotopic variation of Diporeia and Mysis passed on to higher trophic levels via sculpin and coregonine species, highlighting the importance of accounting for such variation in the interpretation of stable isotope data in large, deep lakes (Sierszen et al. 2006).

An enriched $\delta^{13} \mathrm{C}$ signature of siscowet-like compared with lean trout in Great Slave Lake was inconsistent with previous studies that suggested offshore (i.e., depleted) $\delta^{13} \mathrm{C}$ signatures were characteristic of deepwater fishes in large lakes (Harvey et al. 2003). In Great Slave Lake, deepwater fishes (i.e., shortjaw cisco and siscowet-like trout) unexpectedly had a slightly more nearshore signature than their shallow-water counterparts (i.e., cisco and lean trout); whereas in Lake Superior, siscowets and deepwater ciscoes had a more offshore signature than lean trout and cisco (Harvey and Kitchell 2000; Harvey et al. 2003). Lipid content of the tissue samples, rather than actual food web differences, may explain different results from the two lakes (Harvey and Kitchell 2000). Lipids are depleted in $\delta^{13} \mathrm{C}$ (Kiljunen et al. 2006; Murry et al. 2006) and may therefore influence the comparison of the high-fat, deepwater lake trout and coregonines when compared with their lowfat, shallow-water counterparts. Our Great Slave Lake data were analyzed with lipid-corrected $\delta^{13} \mathrm{C}$ values, whereas Harvey and Kitchell (2000) did not make this adjustment to their Lake Superior data. However, lipid extractions were unlikely to be the only explanation for the different $\delta^{13} \mathrm{C}$ patterns between lakes, as a subsequent lipid-corrected data set yielded similar results for Lake Superior (Harvey et al. 2003).

An alternate explanation is that isotopically different carbon sources supplement deepwater food webs in Great Slave Lake and Lake Superior. The steep bathymetry of Great Slave Lake (most deepwater sets were within $100 \mathrm{~m}$ of shore) minimizes the horizontal spatial distinction between shallow-water and deepwater habitats, whereas the more shallow-sloped bathymetry of Lake Superior requires deepwater fishes to feed at a greater distance, often many kilometres, from the nearshore environment. Therefore, carbon settling into deepwater food webs in Great Slave Lake is more likely to be from a littoral source than in Lake Superior. Littoral production is more enriched in $\delta^{13} \mathrm{C}$ than pelagic or profundally derived production (Rau 1978; Vander Zanden and Rasmussen 1999). Enriched $\delta^{13} \mathrm{C}$ settling down a steep slope may result in less distinction in the $\delta^{13} \mathrm{C}$ signatures of deepwater and shallow-water fishes than that found in lakes with shallow-sloped bathymetry. Under this scenario, benthic feeders in shallow-water and deepwater habitats of a steep-sloped lake, such as Great Slave Lake, might be expected to have a more enriched $\delta^{13} \mathrm{C}$ signature than fishes feeding on a more pelagically derived food web.

In summary, morphotypic diversity of lake trout had a significant ontogenetic component linked with an ecological shift between benthic and pelagic feeding. We suggest that resource polymorphisms in lake trout are maintained by resource partitioning in both benthic-feeding (small trout) and pelagic-feeding (large trout) stages. Using an ontogenetic ap- proach and multifaceted data set (shape, buoyancy, habitat depth, stable isotopes), our results offer a new perspective to a current hypothesis on lake trout differentiation (Eshenroder and Burnham-Curtis 1999; Eshenroder 2008). We suggest that lake trout show two types of resource polymorphisms: benthic prey within deepwater habitats and pelagic prey between deepwater and shallow-water habitats. A cross-lake comparison of lake trout morphotypes and the ecology of small and large trout should provide valuable perspective on how habitat depth, a third dimension to benthic and pelagic niches, has contributed to adaptive radiations of fishes in large, deep lakes.

\section{Acknowledgements}

Sam Boucher (Lutsel K'e, Northwest Territories), Shawn Buckley (Hay River, Northwest Territories), Michael Hansen (University of Wisconsin-Stevens Point), and Kelley Thompson (Hay River, Northwest Territories) assisted with field work. 2001 lake trout collections were provided by Jim Reist and Jim Johnson (Fisheries and Oceans Canada (DFO)). George Low (DFO) and Steve Ellis (Wildlife, Lands, and Environment Department of the Lutsel K'e Dene First Nation) helped secure permits for our research. Cisco identifications were verified by Gerald Smith (University of Michigan Museum of Zoology); cisco specimens were deposited in the University of Michigan Fish Division (Cat. Nos. 248557-248562). Allison Evans (Oregon State University) helped collect diet data in laboratory space provided by the Great Lakes Science Center (USGS, Ann Arbor, Michigan). This research was funded by the Fishery Research Program, Great Lakes Fishery Commission.

\section{References}

Ackermann, R.B., and Cheverud, J.M. 2004. Morphological integration in primate evolution. In Phenotypic integration: studying the ecology and evolution of complex phenotypes. Edited by M. Pigliucci and K. Preston. Oxford University Press, Oxford, UK. pp. 302-319.

Alexander, R.M. 1972. The energetics of vertical migration by fishes. In The effects of pressure on living organisms. Symposia of the Society for Experimental Biology. Edited by M.A. Sleigh and A.G. MacDonald. Academic Press, New York. pp. 273-294.

Alexander, R.M. 1993. Buoyancy. In The physiology of fishes. Edited by D.H. Evans. CRC Press, Boca Raton, Fla. pp. 75-97.

Anderson, E.D., and Smith, L.L. 1971. Factors affecting abundance of lake herring (Coregonus artedii Lesueur) in western Lake Superior. Trans. Am. Fish. Soc. 100(4): 691-707. doi:10.1577/ 1548-8659(1971)100<691:FAAOLH>2.0.CO;2.

Bookstein, F.L. 1991. Morphometric tools for landmark data. Cambridge University Press, New York.

Bronte, C.R., Ebener, M.P., Schreiner, D.R., DeVault, D.S., Petzold, M.M., Jensen, D.A., Richards, C., and Lozano, S.J. 2003. Fish community change in Lake Superior, 1970-2000. Can. J. Fish. Aquat. Sci. 60(12): 1552-1574. doi:10.1139/f03-136.

Burnham-Curtis, M.K., and Bronte, C.R. 1996. Otoliths reveal a diverse age structure for humper lake trout in Lake Superior. Trans. Am. Fish. Soc. 125(6): 844-851. doi:10.1577/15488659(1996)125<0844:ORADAS>2.3.CO;2.

Dryer, W.R., Erkkila, L.F., and Tetzloff, C.L. 1965. Food of lake trout in Lake Superior. Trans. Am. Fish. Soc. 94(2): 169-176. doi:10.1577/1548-8659(1965)94[169:FOLTIL]2.0.CO;2.

Elrod, J.H., and Schneider, C.P. 1987. Seasonal bathythermal distri- 
bution of juvenile lake trout in Lake Ontario. J. Great Lakes Res. 13: 1221-1234.

Eschmeyer, P.H., and Phillips, A.M. 1965. Fat content of the flesh of siscowets and lake trout from Lake Superior. Trans. Am. Fish. Soc. 94(1): 62-74. doi:10.1577/1548-8659(1965)94[62:FCOTFO] 2.0.CO;2.

Eshenroder, R.L. 2008. Differentiation of deep-water lake charr Salvelinus namaycush in North American lakes. Environ. Biol. Fishes, 83(1): 77-90. doi:10.1007/s10641-007-9265-y.

Eshenroder, R.L., and Burnham-Curtis, M.K. 1999. Species succession and sustainability of the Great Lakes fish community. In Great Lakes fisheries policy and management: a binational perspective. Edited by W.M. Taylor and C.P. Ferreri. Michigan State University Press, East Lansing, Mich. pp. 145-184.

Eshenroder, R.L., Sideleva, V.G., and Todd, T.N. 1999. Functional convergence among pelagic sculpins of Lake Baikal and deepwater ciscoes of the Great Lakes. J. Great Lakes Res. 25: 847-855.

Evans, M.S. 2000. The large lake ecosystems of northern Canada. Aquat. Ecosyst. Health Manage. 3(1): 65-79. doi:10.1016/ S1463-4988(99)00071-8.

Fisher, S.J., and Swanson, B.L. 1996. Diets of siscowet lake trout from the Apostle Islands region of Lake Superior, 1993. J. Great Lakes Res. 22: 463-468.

Fraley, C., and Raftery, A.E. 2006. MCLUST version 3: an R package for normal mixture modeling and model-based clustering. Department of Statistics, University of Washington, Seattle, Wash.

Harvey, C.J., and Kitchell, J.F. 2000. A stable isotope evaluation of the structure and spatial heterogeneity of a Lake Superior food web. Can. J. Fish. Aquat. Sci. 57(7): 1395-1403. doi:10.1139/ cjfas-57-7-1395.

Harvey, C.J., Schram, S.T., and Kitchell, J.F. 2003. Trophic relationships among lean and siscowet lake trout in Lake Superior. Trans. Am. Fish. Soc. 132(2): 219-228. doi:10.1577/15488659(2003)132<0219:TRALAS>2.0.CO;2.

Hecky, R.E., and Hesslein, R.H. 1995. Contributions of benthic algae to lake food webs as revealed by stable isotope analysis. J. N. Am. Benthol. Soc. 14(4): 631-653. doi:10.2307/1467546.

Henderson, B.A., and Anderson, D.M. 2002. Phenotypic differences in buoyancy and energetics of lean and siscowet lake charr in Lake Superior. Environ. Biol. Fishes, 64(1/3): 203-209. doi:10.1023/A:1016023027437.

Hjelm, J., Persson, L., and Christensen, B. 2000. Growth, morphological variation and ontogenetic niche shifts in perch (Perca fluviatilis) in relation to resource availability. Oecologia (Berlin), 122(2): 190-199. doi:10.1007/PL00008846.

Hrabik, T.R., Jensen, O.P., Martell, S.J.D., Walters, C.J., and Kitchell, J.F. 2006. Diel vertical migration in the Lake Superior pelagic community. I. Changes in vertical migration of coregonids in response to varying predation risk. Can. J. Fish. Aquat. Sci. 63(10): 2286-2295. doi:10.1139/F06-124.

Janssen, J., Marsden, J.E., Bronte, C.R., Jude, D.J., Sitar, S.P., and Goetz, F.W. 2007. Challenges to deep-water reproduction by lake trout: pertinence to restoration in Lake Michigan. J. Great Lakes Res. 33(sp1 Suppl. 1): 59-74. doi:10.3394/03801330(2007)33[59:CTDRBL]2.0.CO;2.

Jastrebski, C.J., and Robinson, B.W. 2004. Natural selection and the evolution of replicated trophic polymorphisms in pumpkinseed sunfish (Lepomis gibbosus). Evol. Ecol. Res. 6: 285-305.

Jennings, M.R. 1989. Use of spring scales for weighing live fish in the field. N. Am. J. Fish. Manage. 9(4): 509-511. doi:10.1577/ 1548-8675(1989)009<0509:MBUOSS>2.3.CO;2.

Keleher, J.J. 1972. Great Slave Lake - effects of exploitation on salmonid community. Fish. Bull. (Washington, D.C.), 29: 741-753.

Kennedy, B.M., Thompson, B.W., and Luecke, C. 2006. Ecological differences between two closely related morphologically similar benthic whitefish (Prosopium spilonotus and Prosopium abyssicola) in an endemic whitefish complex. Can. J. Fish. Aquat. Sci. 63(8): 1700-1709. doi:10.1139/F06-065.

Khan, N.Y., and Qadri, S.U. 1970. Morphological differences in Lake Superior lake char. J. Fish. Res. Board Can. 27: 161-167.

Kiljunen, M., Grey, J., Sinisalo, T., Harrod, C., Immonen, H., and Jones, R.I. 2006. A revised model for lipid-normalizing $\delta^{13} \mathrm{C}$ values from aquatic organisms, with implications for isotope mixing models. J. Appl. Ecol. 43(6): 1213-1222. doi:10.1111/j. 1365-2664.2006.01224.x.

Koelz, W. 1927. Coregonid fishes of the Great Lakes. Bulletin of the Bureau of Fisheries, US Government Printing Office, Washington, D.C.

Langerhans, R.B., Layman, C.A., Langerhans, A.K., and Dewitt, T.J. 2003. Habitat-associated morphological divergence in two neotropical fish species. Biol. J. Linn. Soc. 80(4): 689-698. doi:10.1111/j.1095-8312.2003.00266.x.

Lawrie, A.H., and Rahrer, J.H. 1973. Lake Superior: a case history of the lake and its fisheries. Great Lakes Fishery Commission, Ann Arbor, Mich. Tech. Rep. 19.

Low, G., Stewart, D.B., Day, A.C., and Taptuna, W.E.F. 1999. Comparison of fish harvests from the east arm of Great Slave Lake, N.W.T., by itinerant sport anglers in 1986 and 1994. Can. Fish. Aquat. Sci. Tech. Rep. 2263.

Martin, N.V. 1952. A study of the lake trout, Salvelinus namaycush, in two Algonquin Park, Ontario, lakes. Trans. Am. Fish. Soc. 81(1): 111-137. doi:10.1577/1548-8659(1951)81[111:ASOTLT] 2.0.CO;2.

MathWorks. 2000. MATLAB version 6.2. The MathWorks Inc., Natick, Mass.

Mayer, D.G., and Butler, D.G. 1993. Statistical validation. Ecol. Model. 68(1-2): 21-32. doi:10.1016/0304-3800(93)90105-2.

Moore, S.A., and Bronte, C.R. 2001. Delineation of sympatric morphotypes of lake trout in Lake Superior. Trans. Am. Fish. Soc. 130(6): 1233-1240. doi:10.1577/1548-8659(2001)130<1233:DOSMOL > 2.0.CO;2.

Murry, B.A., Farrell, J.M., Teece, M.A., and Smyntek, P.M. 2006. Effect of lipid extraction on the interpretation of fish community trophic relationships determined by stable carbon and nitrogen isotopes. Can. J. Fish. Aquat. Sci. 63(10): 2167-2172. doi:10. 1139/F06-116.

O'Connell, M.F., Dempson, J.B., and Power, M. 2005. Ecology and trophic relationships of the fishes of Gander Lake, a large, deep, oligotrophic Lake in Newfoundland, Canada. Int. Rev. Hydrobiol. 90(5-6): 486-510. doi:10.1002/iroh.200510804.

Parsons, K.J., and Robinson, B.W. 2007. Foraging performance of diet-induced morphotypes in pumpkinseed sunfish (Lepomis gibbosus) favours resource polymorphism. J. Evol. Biol. 20(2): 673684. doi:10.1111/j.1420-9101.2006.01249.x. PMID:17305833.

Peck, J.W. 1975. Brief life history accounts of five commercial salmonid fishes in Lake Superior. Michigan Department of Natural Resources Fisheries Division, Lansing, Mich. Res. Rep. 1821.

Post, D.M. 2002. Using stable isotopes to estimate trophic position: models, methods, and assumptions. Ecology, 83: 703-718.

Power, M., O’Connell, M.F., and Dempson, J.B. 2005. Ecological segregation within and among Arctic char morphotypes in Gander Lake, Newfoundland. Environ. Biol. Fishes, 73(3): 263-274. doi:10.1007/s10641-005-2137-4.

Rahrer, J.F. 1965. Age, growth, maturity, and fecundity of "humper" lake trout, Isle Royale, Lake Superior. Trans. Am. Fish. Soc. 94(1): 75-83. doi:10.1577/1548-8659(1965) 94[75:AGMAFO]2.0.CO;2.

Rau, G. 1978. Carbon-13 depletion in a subalpine lake: carbon 
flow implications. Science (Washington, D.C.), 201(4359): 901902. doi:10.1126/science.201.4359.901. PMID:17729568.

Rawson, D.S. 1951. Studies of the fish of Great Slave Lake. J. Fish. Res. Board Can. 8: 207-240.

Rawson, D.S. 1953. The bottom fauna of Great Slave Lake. J. Fish. Res. Board Can. 10: 486-520.

Robinson, B.W., and Wilson, D.S. 1994. Character release and displacement in fishes: a neglected literature. Am. Nat. 144(4): 596-627. doi:10.1086/285696.

Robinson, B.W., Wilson, D.S., Margosian, A.S., and Lotito, P.T. 1993. Ecological and morphological differentiation of pumpkinseed sunfish in lakes without bluegill sunfish. Evol. Ecol. 7(5): 451-464. doi:10.1007/BF01237641.

Robinson, B.W., Januszkiewicz, A.J., and Koblitz, J.C. 2008. Survival benefits and divergence of predator-induced behavior between pumpkinseed sunfish ecomorphs. Behav. Ecol. 19(2): 263-271. doi:10.1093/beheco/arm133.

Saino, T., and Hattori, A. $1980 .{ }^{15} \mathrm{~N}$ natural abundance in oceanic suspended particulate matter. Nature (London), 283(5749): 752754. doi:10.1038/283752a0.

Sampson, P.D., Bookstein, F.L., Sheehan, F.H., and Bolson, E.L. 1996. Eigenshape analysis of left ventricular outlines from contrast ventriculograms. In Advances in morphometrics. Edited by L.F. Marcus, M. Corti, and A. Loy. Plenum Press, New York. pp. 211-233.

Schluter, D. 1995. Adaptive radiation in sticklebacks: trade-offs in feeding performance and growth. Ecology, 76(1): 82-90. doi:10. 2307/1940633.

Schluter, D., and McPhail, J.D. 1992. Ecological character displacement and speciation in sticklebacks. Am. Nat. 140(1): 85108. doi:10.1086/285404.

Schluter, D., and McPhail, J.D. 1993. Character displacement and replicate adaptive radiation. Trends Ecol. Evol. 8(6): 197-200. doi:10.1016/0169-5347(93)90098-A.

Schmidt, S.N. 2008. Stable isotope analysis of the Laurentian Great Lakes food webs: quantifying spatial and temporal food web differences. Ph.D. thesis, University of Wisconsin, Center for Limnology, Madison, Wis.

Schmidt, S.N., Olden, J.D., Solomon, C.T., and Vander Zanden, M.J. 2007. Quantitative approaches to the analysis of stable isotope food web data. Ecology, 88(11): 2793-2802. doi:10.1890/ 07-0121.1. PMID:18051648.

Selgeby, J.H. 1988. Comparative biology of the sculpins of Lake Superior. J. Great Lakes Res. 14: 44-51.

Sierszen, M.E., Peterson, G.S., and Scharold, J.V. 2006. Depthspecific patterns in benthic-planktonic food web relationships in Lake Superior. Can. J. Fish. Aquat. Sci. 63(7): 1496-1503. doi:10.1139/F06-057.

Skulason, S., and Smith, T.B. 1995. Resource polymorphisms in vertebrates. Trends Ecol. Evol. 10(9): 366-370. doi:10.1016/ S0169-5347(00)89135-1.

Smith, S.H. 1964. Status of the deepwater cisco population of Lake Michigan. Trans. Am. Fish. Soc. 93(2): 155-163. doi:10.1577/ 1548-8659(1964)93[155:SOTDCP]2.0.CO;2.

Smith, T.B., and Skulason, S. 1996. Evolutionary significance of resource polymorphisms in fishes, amphibians, and birds. Annu. Rev. Ecol. Syst. 27(1): 111-133. doi:10.1146/annurev.ecolsys. 27.1.111.
Smith, G.R., and Todd, T.N. 1984. Evolution of species flocks of fishes in north temperate lakes. In Evolution of fish species flocks. Edited by A.A. Echelle and I. Kornfield. University of Main at Orono Press, Orono, Maine. pp. 45-68.

SPSS. 2003. SPSS v. 12.0 for Windows. SPSS Inc., Chicago, Ill.

Stewart, D.B. 1997. A review of the status and harvests of fish stocks in the North Slave area, Northwest Territories. Can. Manuscr. Rep. Fish. Aquat. Sci. 2393.

Svanback, R., and Eklov, P. 2003. Morphology dependent foraging efficiency in perch: a trade-off for ecological specialization? Oikos, 102(2): 273-284. doi:10.1034/j.1600-0706.2003.12657.x.

Svanback, R., and Eklov, P. 2004. Morphology in perch affects habitat specific feeding efficiency. Funct. Ecol. 18(4): 503-510. doi:10.1111/j.0269-8463.2004.00858.x.

Sweeting, C.J., Polunin, N.V.C., and Jennings, S. 2006. Effects of chemical lipid extraction and arithmetic lipid correction on stable isotope ratios of fish tissues. Rapid Commun. Mass Spectrom. 20(4): 595-601. doi:10.1002/rcm.2347. PMID:16429479.

Van Oosten, J., and Deason, H.J. 1938. The food of the lake trout (Cristivomer namaycush namaycush) and of the lawyer (Lota maculosa) of Lake Michigan. Trans. Am. Fish. Soc. 67(1): 155177. doi:10.1577/1548-8659(1937)67[155:TFOTLT]2.0.CO;2.

Vander Zanden, M.J., and Rasmussen, J.B. 1999. Primary consumer $\delta^{13} \mathrm{C}$ and $\delta^{15} \mathrm{~N}$ and the trophic position of aquatic consumers. Ecology, 80: 1395-1404. doi:10.1890/0012-9658(1999) 080[1395:PCCANA]2.0.CO;2.

Vander Zanden, M.J., and Vadeboncoeur, Y. 2002. Fishes as integrators of benthic and pelagic food webs in lakes. Ecology, 83(8): 2152-2161. doi:10.1890/0012-9658(2002)083[2152:FAIOBA] 2.0.CO;2.

Vander Zanden, M.J., Shuter, B.J., Lester, N.P., and Rasmussen, J.B. 2000. Within- and among-population variation in the trophic position of a pelagic predator, lake trout (Salvelinus namaycush). Can. J. Fish. Aquat. Sci. 57(4): 725-731. doi:10.1139/ cjfas-57-4-725.

Ward-Campbell, B.M.S., and Beamish, F.W.H. 2005. Ontogenetic changes in morphology and diet in the snakehead, Channa limbata, a predatory fish in western Thailand. Environ. Biol. Fishes, 72(3): 251-257. doi:10.1007/s10641-004-1744-9.

Werner, E.E., and Hall, D.J. 1988. Ontogenetic habitat shifts in bluegill: the foraging rate-predation risk trade-off. Ecology, 69(5): 1352-1366. doi:10.2307/1941633.

Zelditch, M.L., Swiderski, D.L., Sheets, H.D., and Fink, W.L. 2004. Geometric morphometrics for biologists: a primer. Elsevier Academic Press, New York.

Zimmerman, M.S. 2007. A field study of brook stickleback morphology: multiple predators and multiple traits. Can. J. Zool. 85(2): 250-260. doi:10.1139/Z07-003.

Zimmerman, M.S., Krueger, C.C., and Eshenroder, R.L. 2006. Phenotypic diversity of lake trout in Great Slave Lake: differences in morphology, buoyancy, and habitat depth. Trans. Am. Fish. Soc. 135(4): 1056-1067. doi:10.1577/T05-237.1.

Zimmerman, M.S., Krueger, C.C., and Eshenroder, R.L. 2007. Morphological and ecological differences between shallow- and deep-water morphotypes in Lake Mistassini, Quebec. J. Great Lakes Res. 33(1): 156-169. doi:10.3394/0380-1330(2007) 33[156:MAEDBS]2.0.CO;2. 